\title{
PENINGKATAN KEMAMPUAN MENULIS SISWA KELAS 3 SD DENGAN KEGIATAN MEMBACA PADA MORNING ACTIVITIES
}

\author{
Rizka Amalia \\ SDIT Insan Kamil Sidoarjo \\ (amaliaonwrites@gmail.com) \\ Endang Wahju Andjariani \\ STKIP PGRI Sidoarjo \\ (endang.wahju1818@gmail.com)
}

\begin{abstract}
Abstrak
Penelitian ini bertujuan untuk mengetahui apakah kegiatan membaca dalam program morning activities dapat meningkatkan kemampuan menulis siswa kelas 3-D SDIT Insan Kamil Sidoarjo. Untuk mencapai tujuan tersebut dilakukan penelitian tindakan kelas (PTK). PTK dilakukan dengan 2 siklus yang diawali tahap pratindakan. Pada tahap pratindakan, hasil pratindakan hanya diperoleh $25 \%$ tingkat keberhasilannya. Hal tersebut disebabkan kemampuan membaca yang rendah dan tak adanya media atau program yang memudahkan siswa menulis. Dengan fakta tersebut, dilakukan tindakan siklus I. Pada siklus I, hasil yang diperoleh masih jauh dari tujuan. Hasilnya hanya diperoleh $45 \%$ saja. Hal tersebut disebabkan faktor membaca lantang yang kurang. Karena itu dilakukan tindakan siklus II. Siklus II, siswa mencapai 95\%. Hal tersebut menunjukkan keberhasilan dari penelitian tindakan yang dilakukan pada siswa kelas 3-D.
\end{abstract}

Kata kunci : menulis, membaca, morning activities

\begin{abstract}
This study aims to determine wether reading activities in morning activities program can improve student's ability in the third class D of SDIT Insan Kamil Sidoarjo. To achieve these objectives, classroom action research (CAR) is conducted. This study was conducted in 2 cycles starting from pre-action stage. At the pre-action stage, the result showes $25 \%$ of successful rate refering to the low reading ability and lack of media of programs to make students easy to write. The result of the cycle I was $45 \%$ and was still far from objectivives because the loud reading factor that was rarely conducted. Then, cycle II was conducted. The result of cycle II was $95 \%$, meaning that CAR was successfully conducted on students of third class D.
\end{abstract}

Keywords : writing, reading, morning activities

\section{PENDAHULUAN}


Sebagaimana firman Allah dalam surat Al-Alaq ayat 1-5, Iqra (baca). Membaca itu sangat penting. Firman Allah tersebut tak lantas turun tanpa maksud. Membaca dapat membuka wawasan tentang dunia dan isinya.

Angka mengejutkan terlihat dari hasil survei yang dilakukan Programmme for International Student Assessment (PISA) di bawah Organization Economic Cooperation and Development (OECD) pada tahun 2012. Lembaga yang melakukan pemetaan kemampuan matematika, membaca, dan sains tersebut mendapatkan angka bahwa Indonesia berada pada peringkat terbawah dari 65 negara di dunia untuk minat membaca (dalam Menghidupkan Semangat Baca Anak, Duta Masyarakat, 14 Desember 2015).

Meskipun fakta minat membaca masih sangat rendah tetapi kemampuan pemahaman anak Indonesia sudah dapat dikatakan baik. Dengan fakta tersebut apakah bangsa Indonesia bisa maju? Hal inilah yang menjadi tantangan bagi para generasi penerus bangsa karena temuan tentang kemampuan awal anak membaca bisa menjadi potensi untuk menghidupkan kembali budaya membaca anak Indonesia.
Rendahnya tingkat membaca sangat berhubungan dengan keterampilan menulis. Bila minat membaca rendah maka minat menulis juga. Kegiatan menulis sangat dipengaruhi kegiatan membaca. Keduanya bahkan tak dapat dipisahkan.

Membaca adalah suatu proses yang dilakukan serta digunakan oleh pembaca untuk memperoleh pesan yang disampaikan penulis melalui media bahasa tulis (Tarigan, 1984). Kridalaksana (1982) mengemukakan bahwa dalam kegiatan membaca melibatkan dua hal, yaitu (1) pembaca yang berimplikasi adanya pemahaman dan (2) teks yang berimplikasi adanya penulis.

Dari segi linguistik membaca adalah suatu proses penyandian kembali dan pembahasan sandi (a recording and decoding process), berlainan dengan berbicara dan menulis yang justru melibatkan penyandian (encoding). Sebuah aspek pembacaan sandi (decoding) adalah menghubungkan katakata tulis (written word) dengan makna bahasa lisan (oral language meaning) yang mencakup pengubahan tulisan/cetakan menjadi bunyi yang bermakna (Tarigan, 1984:8). Dari 
beberapa definisi tersebut dapat disimpulkan bahwa membaca adalah suatu proses yang dilakukan pembaca yang dapat memberikan informasi atau pesan.

Sementara itu, menulis dapat diartikan sebagai kegiatan menuangkan ide/gagasan dengan menggunakan bahasa tulis sebagai media penyampai (Tarigan, 1986). Menurut Djago Tarigan menulis berarti mengekpresikan secara tertulis gagasan, ide, pendapat, atau pikiran dan perasaan. Dari kedua definisi tersebut, menulis dapat diartikan sebagai upaya atau kegiatan menuangkan ide, pikiran, dan perasaan dalam sebuah media tertentu.

Keterampilan menulis juga termasuk dalam literasi. Secara bahasa, literasi adalah keberaksaraan, yaitu kemampuan menulis dan membaca (kbbi.kemendikbud.go.id/entri/literasi). Dalam bahasa Inggris, literacy artinya kemampuan membaca dan menulis. Literacy berasal dari bahasa Latin, literatus, yang berarti "a learned person" atau orang yang belajar.

Dari beberapa definisi literasi dapat diketahui bahwa literasi adalah kemampuan untuk mengenali dan memahami ide-ide yang disampaikan, baik secara lisan maupun tulis dan bisa berupa audio, visual, atau keduanya.

Mengacu pada fenomena literasi di atas terdapat fenomena unik yang terdapat di Sekolah Dasar Islam Terpadu (SDIT) di Sidoarjo, yakni di SDIT Insan Kamil Sidoarjo. Di SDIT Insan Kamil tersebut terdapat program morning activities. Selama kurang lebih 10 menit, siswa diberikan waktu untuk membaca. Hal tersebut bertolak belakang dari hasil survei lembaga luar negeri yang menyatakan bahwa indeks membaca masyarakat Indonesia begitu rendah.

Faktanya, upaya peningkatan literasi atau menarik minat membaca sudah dilakukan lembaga pendidikan seperti SDIT Insan Kamil Sidoarjo sebelum pemerintah menggulirkan program wajib baca. Didukung juga dengan adanya Permendikbud Nomor 23 Tahun 2015 tentang Penumbuhan Budi Pekerti maka kegiatan yang dilakukan layak dilakukan. Dengan begitu semakin jelas dan kuat, serta terjadi sinergitas antara pemerintah dan lembaga pendidikan.

Program morning activities di SDIT Insan Kamil Sidoarjo sendiri juga dilakukan untuk meningkatkan minat baca dan mengembangkan kemampuan 
menulis siswa. Akan tetapi, pada awalnya tidak maksimal dan tidak terstruktur. Padahal di lapangan, dapat diketahui bahwa kegiatan pagi ini sangat membantu dalam meningkatkan kemampuan menulis.

Kegiatan menulis siswa SDIT Insan Kamil memang pada awalnya kurang dan lemah. Tidak ada sarana untuk mendukung tersalurkannya bakat dan minat siswa dalam literasi. Karena itulah, morning activities diatur kembali dan lebih terstruktur. Berikut ini merupakan hasil dari kegiatan membaca pagi yang didapat dari hasil siswa kelas 3.

\section{Kutipan 1}

Aku saat libur cuma di rumah saja terus membaca, mengaji, terus tidur. terus aku bantu mama membersihkan rumah. semua seperti biasa. jadi aku cuma dirumah saja.

Kalau nanti libur lagi baru pergi ke yogya sama mama sama papa kakak. Pasti seneng soalnya pergi sama-ama. (S20)

Kutipan tersebut adalah milik salah satu siswa kelas 3-D. Dari kutipan tersebut dapat dilihat bahwa terdapat kekurangan dalam segi kepaduan paragraf dan penggunaan ejaan dan tanda baca. Untuk itu, dilakukanlah Penelitian Tindakan Kelas (PTK) di SDIT Insan Kamil Sidoarjo untuk mendalami dan meningkatkan kemampuan menulis siswa. Penelitian dilakukan pada siswa kelas 3-D. Hal tersebut dilakukan dengan harapan dapat meningkatkan kemampuan menulis siswa kelas 3-D.

Dengan hal tersebut, maka dirumuskanlah masalah, yaitu "Apakah kegiatan membaca dalam program morning activities dapat meningkatkan kemampuan menulis siswa kelas 3-D SDIT Insan Kamil Sidoarjo?”. Berdasarkan rumusan masalah maka bentuk tindakan pemecahan masalahnya adalah melakukan penelitian tindakan kelas. Penelitian tindakan kelas ini melibatkan guru dan perencanaan tindakan. Perencanaan tindakan akan ditindaklanjuti dengan melakukan kegiatan membaca lantang pada saat morning activities selama 25 menit. 10 menit untuk membaca, selebihnya digunakan untuk menulis.

Sejalan dengan rumusan masalah, tujuan penelitian tersebut adalah untuk mengetahui apakah kegiatan membaca dalam program morning activities dapat meningkatkan kemampuan menulis 
siswa kelas 3-D SDIT Insan Kamil Sidoarjo.

\section{METODE}

Penelitian ini merupakan penelitian tindakan kelas (PTK). PTK merupakan jenis penelitian yang dilakukan untuk memperbaiki pembelajaran di kelas (Daryanto:2011). Model PTK tersebut diawali dengan tahap identifikasi masalah. Dari proses tersebut disusunlah rancangan penelitian. Rancangan penelitian diawali dengan rencana penelitian, lalu tindakan. Ketika melakukan tindakan, dilakukan observasi dan direfleksi. Dari hasil refleksi kemudian dilanjutkan dengan siklus 2. Bila belum mendapat hasil yang sesuai dengan tujuan, siklus dapat ditambah hingga target atau tujuan penelitan tercapai. dilakukan tahap observasi masalah. Ternyata ditemukan kelemahan dalam hal menulis siswa. Setelah itu, merumusakan masalahnya. Untuk lebih jelasnya, perhatikan bagan di bawah ini.

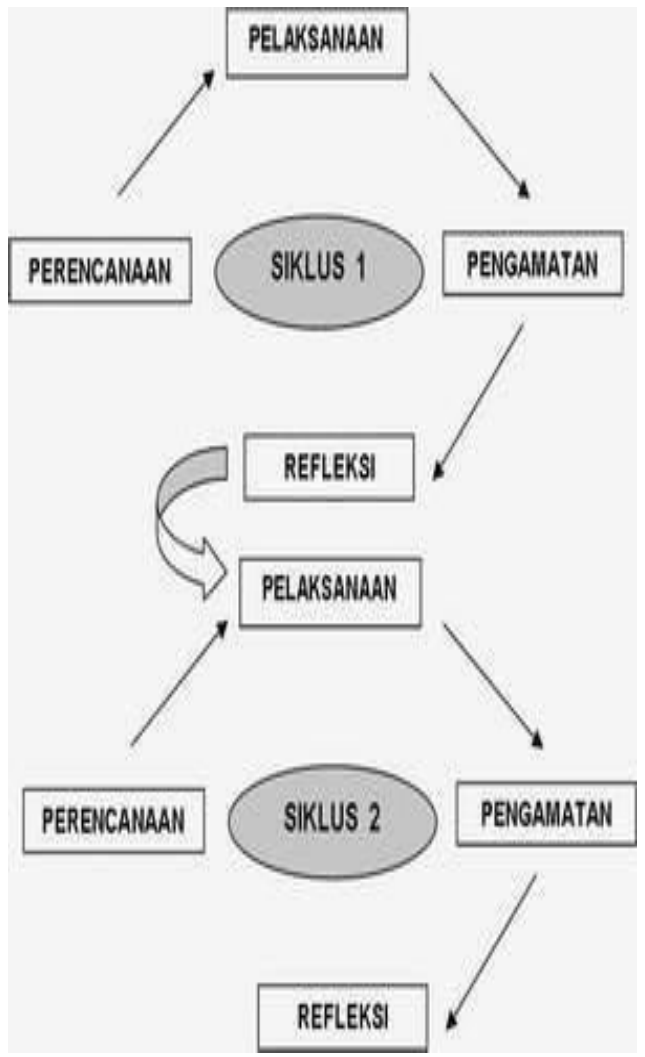

Gambar 1. Bagan Model PTK

Lokasi penelitian adalah SDIT Insan Kamil Sidoarjo yang berlokasi di Jalan Pecantingan RT 12, RW 4, Sekardangan, Kecamatan Sidoarjo, Kabupaten Sidoarjo, Jawa Timur 61215.

Subjek penelitian ini adalah siswa kelas 3-D yang berjumlah 32 siswa putri. Subjek penelitian dalam hal ini heterogen dilihat dari kemampuannya, yakni ada yang memiliki kemampuan tinggi, sedang, dan rendah. Dari jumlah keseluruhan hanya diambil untuk siswa yang memiliki literasi sedang. Jumlahnya 20 siswa putri. Nama subjek disingkat dengan memberikan inisial 
atau kode subjek. Berikut ini daftar subjek penelitian.

Tabel 1. Tabel Subjek Penelitian

\begin{tabular}{cccc}
\hline No & $\begin{array}{c}\text { Subjek } \\
\text { Penelitian }\end{array}$ & No & $\begin{array}{c}\text { Subjek } \\
\text { Penelitian }\end{array}$ \\
\hline 1 & S1 & 11 & S11 \\
\hline 2 & S2 & 12 & S12 \\
\hline 3 & S3 & 13 & S13 \\
\hline 4 & S4 & 14 & S14 \\
\hline 5 & S5 & 15 & S15 \\
\hline 6 & S6 & 16 & S16 \\
\hline 7 & S7 & 17 & S17 \\
\hline 8 & S8 & 18 & S18 \\
\hline 9 & S9 & 19 & S19 \\
\hline 10 & S10 & 20 & S20 \\
\hline
\end{tabular}

Data dalam penelitian ini adalah tulisan siswa kelas 3-D ketika moorning activities. Sumber datanya adalah siswa kelas 3-D SDIT Insan Kamil Sidoarjo. Jumlahnya hanya diambil 20 siswa putri saja. Data tersebut dikumpulkan sehingga teknik pengumpulan data dilakukan dengan mengumpulkan tulisan siswa kelas 3-D. Waktu penyelenggaraan penelitian ini adalah semester 2 tahun ajaran 2016/2017.

Analisis data dilakukan sesuai dengan prosedur penelitian, antara lain seleksi data, pengoreksian data, pemboboan data, dan penyimpulan data. Dalam melakukan proses terssebut, dibuat indikator penilaian. Adapun indikator tersebut dapat dilihat sebagai berikut.

Tabel 2. Indikator Penilaian

\begin{tabular}{cccl}
\hline No & \multicolumn{1}{c}{ Aspek } & Skor & \multicolumn{1}{c}{ Deskriptor } \\
\hline 1 & Kepaduan & 3 & $\begin{array}{l}\text { Antarkalimat berhubungan dan terdapat } \\
\text { paragraph }\end{array}$ \\
\hline & 2 & $\begin{array}{l}\text { Antar kalimat tidak berhubungan dan } \\
\text { terdapat paragraf }\end{array}$ \\
\hline Bjaan dan Tanda & 3 & $\begin{array}{l}\text { Antar kalimat tidak berhubungan dan tidak } \\
\text { terdapat paragraf }\end{array}$ \\
\hline & 2 & $\begin{array}{l}\text { Tidak terdapat kesalahan struktur kalimat, } \\
\text { penggunaan ejaan dan tanda baca }\end{array}$ \\
\hline & 2 & $\begin{array}{l}\text { Terdapat beberapa (tidak lebih dari 3) } \\
\text { kesalahan struktur kalimat, penggunaan } \\
\text { ejaan dan tanda baca }\end{array}$ \\
\hline & 1 & $\begin{array}{l}\text { Terdapat banyak (lebih dari 3) kesalahan } \\
\text { struktur kalimat, penggunaan ejaan dan tanda } \\
\text { baca }\end{array}$ \\
\hline
\end{tabular}


Pada tahap penyimpulan, kriteria keberhasilan siswa dalam menulis data disimpulkan pada tabel berikut.

Tabel 3. Kriteria Penyimpulan

\begin{tabular}{cccc}
\hline $\begin{array}{c}\text { Taraf } \\
\text { Penguasaan }\end{array}$ & Kualifikasi & Nilai Angka & Keterangan \\
\hline $76-100 \%$ & Sangat baik & $5-6$ & Berhasil \\
\hline $51-75 \%$ & Baik & $3-4$ & Kurang berhasil \\
\hline $0-50 \%$ & Kurang & $0-2$ & Tidak berhasil \\
\hline
\end{tabular}

\section{HASIL DAN PEMBAHASAN}

Dari segi hasil pratindakan, tulisan siswa ternyata tidak memenuhi standar prosentase minimal pencapaian indikator penilaian menulis. Hasil penelitian tahap pratindakan hanya 2 siswa yang memenuhi indikator penilaian menulis. Selebihnya 18 siswa hanya mampu mencapai dua indikator penilaian dengan level nilai 1 dan 2 saja.

Dari 20 subjek penelitian, 2 siswa memperoleh skor 6 (10\%), 2 siswa memperoleh skor 5 (10\%), 2 siswa lagi memperoleh skor 4 (10\%), 4 siswa memperoleh skor 3 (20\%), dan 10 siswa memperoleh skor 2 (50\%). Lebih jelasnya, mari simak tabel berikut ini.

Tabel 4. Hasil Pratindakan

\begin{tabular}{ccccccc}
\hline No & Nama & \multicolumn{2}{c}{$\begin{array}{c}\text { Aspek } \\
\text { Penilaian }\end{array}$} & $\begin{array}{c}\text { Total } \\
\text { Skor }\end{array}$ & Nilai & Predikat \\
\cline { 2 - 4 } & & $\mathbf{1}$ & $\mathbf{2}$ & & & \\
\hline 1 & S1 & 2 & 1 & 3 & 50 & KB \\
\hline 2 & S2 & 1 & 1 & 2 & 33 & KB \\
\hline 3 & S3 & 2 & 1 & 3 & 50 & KB \\
\hline 4 & S4 & 1 & 1 & 2 & 33 & KB \\
\hline 5 & S5 & 3 & 2 & 5 & 83 & SB \\
\hline 6 & S6 & 2 & 1 & 3 & 33 & KB \\
\hline 7 & S7 & 1 & 1 & 2 & 33 & KB \\
\hline 8 & S & 2 & 2 & 4 & 68 & B \\
\hline 9 & S9 & 2 & 2 & 4 & 68 & B \\
\hline 10 & S10 & 2 & 1 & 3 & 50 & KB \\
\hline 11 & S11 & 3 & 2 & 5 & 83 & SB \\
\hline 12 & S12 & 3 & 3 & 6 & 100 & SB \\
\hline
\end{tabular}




\begin{tabular}{ccccccc}
\hline 13 & S13 & 1 & 1 & 2 & 33 & KB \\
\hline 14 & S14 & 1 & 1 & 2 & 33 & KB \\
\hline 15 & S15 & 1 & 1 & 2 & 33 & KB \\
\hline 16 & S16 & 1 & 1 & 2 & 33 & KB \\
\hline 17 & S17 & 3 & 3 & 6 & 100 & SB \\
\hline 18 & S18 & 1 & 1 & 2 & 33 & KB \\
\hline 19 & S19 & 1 & 1 & 2 & 33 & KB \\
\hline 20 & S20 & 1 & 1 & 2 & 33 & KB \\
\hline
\end{tabular}

Berdasarkan hasil penelitian di atas dapat diketahui bahwa kemampuan menulis siswa kelas 3-D SDIT Insan Kamil Sidoarjo pada kegiatan pratindakan tergolong rendah. Hanya $10 \%$ yang memenuhi standar penilaian menulis. Setelah dilakukan analisis dan refleksi pada tahap pratindakan, peneliti meminta saran dan diskusi bersama guru pengajar lainnya untuk merumuskan masalah dan mencari solusinya.

Hasil analisis dari kegiatan pratindakan menunjukkan guru tidak menggunakan media diary. Karena itu peneliti akan menggunakan media tersebut. Adanya media tersebut akan membantu jalannya tindakan kelas. Selain itu, penggunaan media dimanfaatkan dalam program moorning activities yang sudah berjalan sebagai upaya meningkatkan keterampilan menulis siswa kelas 3-D SDIT Insan Kamil Sidoarjo dengan menggunakan media diary.
Hasil penelitian tindakan I adalah tulisan siswa yang belum direvisi. Hal tersebut digunakan untuk menilai pelaksanaan tindakan, yakni penggunaan media diary dan pembacaan lantang yang dilakukan.

Tulisan siswa dinilai berdasarkan aspek penilaian, antara lain: (1) kepaduan dan (2) penggunaan ejaan dan tanda baca. Kedua aspek tersebut dijabarkan pada tiap indikator. Dengan begitu didapat hasil nilai maksimal adalah 6, sedangkan nilai minimum adalah 1.

Pada akhir tindakan I didapat hasil sebagai berikut: (1) Dari jumlah keseluruhan siswa terdapat hanya 5 siswa yang mendapat nilai 6 (25\%), (2) 4 siswa mendapat skor 5 (20\%), (3) 6 siswa mendapat nilai 4 (30\%), dan 5 siswa mendapat nilai 3 (25\%). Lebih jelasnya sebagaimana tabel berikut ini. 
Tabel 5. Hasil Tindakan I

\begin{tabular}{ccccccc}
\hline No & Nama & \multicolumn{2}{c}{$\begin{array}{c}\text { Aspek } \\
\text { Penilaian }\end{array}$} & $\begin{array}{c}\text { Total } \\
\text { Skor }\end{array}$ & Nilai & Predikat \\
\cline { 3 - 5 } & & $\mathbf{1}$ & $\mathbf{2}$ & & & \\
\hline 1 & S1 & 2 & 2 & 4 & 68 & B \\
\hline 2 & S2 & 2 & 1 & 3 & 50 & B \\
\hline 3 & S3 & 3 & 2 & 5 & 83 & SB \\
\hline 4 & S4 & 2 & 1 & 3 & 50 & KB \\
\hline 5 & S5 & 3 & 3 & 6 & 100 & SB \\
\hline 6 & S6 & 3 & 2 & 5 & 83 & SB \\
\hline 7 & S7 & 2 & 1 & 3 & 50 & KB \\
\hline 8 & S8 & 3 & 2 & 5 & 83 & SB \\
\hline 9 & S9 & 3 & 3 & 6 & 100 & SB \\
\hline 10 & S10 & 3 & 2 & 5 & 83 & SB \\
\hline 11 & S11 & 3 & 3 & 6 & 100 & SB \\
\hline 12 & S12 & 3 & 3 & 6 & 100 & SB \\
\hline 13 & S13 & 2 & 2 & 4 & 68 & B \\
\hline 14 & S14 & 2 & 2 & 4 & 68 & B \\
\hline 15 & S15 & 2 & 1 & 3 & 50 & KB \\
\hline 16 & S16 & 2 & 2 & 4 & 68 & B \\
\hline 17 & S17 & 3 & 3 & 6 & 100 & SB \\
\hline 18 & S18 & 2 & 2 & 4 & 68 & B \\
\hline 19 & S19 & 3 & 2 & 5 & 83 & SB \\
\hline 20 & S20 & 2 & 1 & 3 & 50 & KB \\
\hline & & & & & & \\
\hline
\end{tabular}

Dari hasil tersebut, tidak didapati siswa yang mendapatkan nilai 2. Skor minimal ada pada nilai 3. Hal tersebut menunjukkan bahwa tindakan I belum bisa dikatakan berhasil. Tindakan I yang dilakukan hanya $25 \%$ saja yang mendapat skor maksimal. Hasil tersebut dikarenakan kesalahan masih terjadi dalam tulisan siswa kelas 3-D. kesalahan tersebut dapat dilihat pada kutipan tulisan berikut ini.

\section{Kutipan 3}

Saat itu Muhammad Masih kecil dan ibu Aminah Bertemu dengan hanifah dia bercakap-cakap dan dia pun pergi lalu tiba-tiba hanifah ketakutan karena rasa takutnya , ada 2 malaikat yang menghampiri. (S15)

Dari kutipan di atas, sangat tampak kesalahannya, yakni pada ejaan yang digunakan dan penggunaan tanda baca. Bila dibaca, membuat pembacanya bingung dan capek sebab 
tak ada tanda baca titik (.). Selain itu, isi cerita juga salah. Harusnya bukan Hanifah tetapi Halimah. Urutan cerita yang dituliskan kembali oleh Nashwa tidak utuh. Jalan ceritanya salah.

Mengacu pada masalah dan faktor-faktor penyebab timbulnya masalah yang ditemukan pada pelaksanaan tindakan I maka peneliti berdiskusi dengan guru pengajar lain untuk merumuskan kembali solusi atau tindakan lain yang dapat meningkatkan kemampuan menulis siswa kelas 3-D. Berdasarkan identifikasi masalah tindakan I, dibuatlah rencana tindakan II. Langkah-langkah perencanaan pada tindakan II, antara lain:

(1) Siswa tetap melakukan senam AEK.

(2) Guru membacakan cerita dengan lantang dan diulang.

(3) Guru memberikan pengarahan kepada siswa agar menulis dengan tepat dengan memberikan arahan agar memudahkan siswa menuliskan dan mengurutkan ceritanya.

Seperti pada tindakan I, penilaian terhadap tulisan siswa didasarkan pada kriteria yang sama. Dari hasil yang didapatkan, kemampuan menulis siswa pada tindakan II berkembang pesat. Yang awalnya hanya mencapai sekitar $45 \%$ saja dengan kategori baik, sekarang bisa mencapai 95\%. Karena masih ada 1 siswa yang belum bisa mencapai skor maksimal 6. Lebih jelasnya, ada dalam tabel berikut ini.

Tabel 6. Hasil Tindakan II

\begin{tabular}{ccccccc}
\hline No & Nama & \multicolumn{2}{c}{$\begin{array}{c}\text { Aspek } \\
\text { Penilaian }\end{array}$} & $\begin{array}{c}\text { Total } \\
\text { Skor }\end{array}$ & Nilai & Predikat \\
\cline { 2 - 4 } & & $\mathbf{1}$ & $\mathbf{2}$ & & & \\
\hline 1 & S1 & 3 & 3 & 6 & 100 & SB \\
\hline 2 & S2 & 3 & 3 & 6 & 100 & SB \\
\hline 3 & S3 & 3 & 3 & 6 & 100 & SB \\
\hline 4 & S4 & 3 & 3 & 6 & 100 & SB \\
\hline 5 & S5 & 3 & 3 & 6 & 100 & SB \\
\hline 6 & S6 & 3 & 3 & 6 & 100 & SB \\
\hline 7 & S7 & 3 & 3 & 6 & 100 & SB \\
\hline 8 & S8 & 3 & 3 & 6 & 100 & SB \\
\hline 9 & S9 & 3 & 3 & 6 & 100 & SB \\
\hline 10 & S10 & 3 & 3 & 6 & 100 & SB \\
\hline 11 & S11 & 3 & 3 & 6 & 100 & SB \\
\hline 12 & S12 & 3 & 3 & 6 & 100 & SB \\
\hline 13 & S13 & 3 & 3 & 6 & 100 & SB \\
\hline
\end{tabular}




\begin{tabular}{ccccccc}
\hline 14 & S14 & 3 & 3 & 6 & 100 & SB \\
\hline 15 & S15 & 3 & 3 & 6 & 100 & SB \\
\hline 16 & S16 & 3 & 3 & 6 & 100 & SB \\
\hline 17 & S17 & 3 & 3 & 6 & 100 & SB \\
\hline 18 & S18 & 3 & 3 & 6 & 100 & SB \\
\hline 19 & S19 & 3 & 3 & 6 & 100 & SB \\
\hline 20 & S20 & 3 & 2 & 5 & 83 & SB \\
\hline
\end{tabular}

Dari hasil tindakan II tersebut terlihat bahwa kemampuan menulis siswa sudah memenuhi kriteria. Seluruh indikator yang ada dapat dikuasai siswa dengan sangat baik.

Dilihat dari aspek kepaduan, siswa sudah dapat melanjutkan kalimat berikutnya dengan baik dengan memberikan kata sambung yang sesuai dan bervariasi. Perhatikan kutipan berikut ini.

\section{Kutipan 5}

Beberapa bulan yang lalu, Rasulullah pergi ke Mekkah untuk berdagang. Biasanya mereka bergantian melapor ke Khodijah tapi kali ini mereka tidak bergantian melapor melainkan Rasulullah yang melapor ke Khodijah. Sebelum mereka ke Khodijah, Rasulullah bertawaf mengelilingi Ka'bah 7 kali. (S11)

Tulisan di atas, sudah sangat bagus. Aspek kepaduan sudah baik dan tepat. Begitu juga dengan penggunaan tanda baca dan ejaannya.
Berdasarkan hasil dapat diketahui bahwa dari 20 subjek penelitian, 2 siswa memperoleh skor 6 (10\%), 2 siswa memperoleh skor 5 (10\%), 2 siswa lagi memperoleh skor 4 (10\%), 4 siswa memperoleh skor 3 (20\%), dan 10 siswa memperoleh skor 2 (50\%). Prosentase tersebut menunjukkan kualifikasi menulis siswa kelas 3-D masih rendah sehingga diperlukan tindakan.

Pada akhir tindakan I didapat hasil sebagai berikut: (1) Dari jumlah keseluruhan siswa terdapat hanya 5 siswa yang mendapat nilai $6(25 \%),(2) 4$ siswa mendapat skor 5 (20\%), (3) 6 siswa mendapat nilai $4(30 \%)$, dan 5 siswa mendapat nilai 3 (25\%). Dengan demikian, tindakan I masih belum bisa dikatakan berhasil sehingga memerlukan tindakan II.

Pada tindakan II didapatkan hasil yang menggembirakan. Yang awalnya hanya mencapai sekitar $45 \%$ saja dengan kategori baik, sekarang bisa mencapai 
95\%. Karena masih ada 1 siswa yang belum bisa mencapai skor maksimal 6 . tindakan untuk penelitian ini dapat dilihat pada diagram batang berikut.

$$
\text { Untuk lebih jelasnya, }
$$

perkembangan atau tingkat keberhasilan

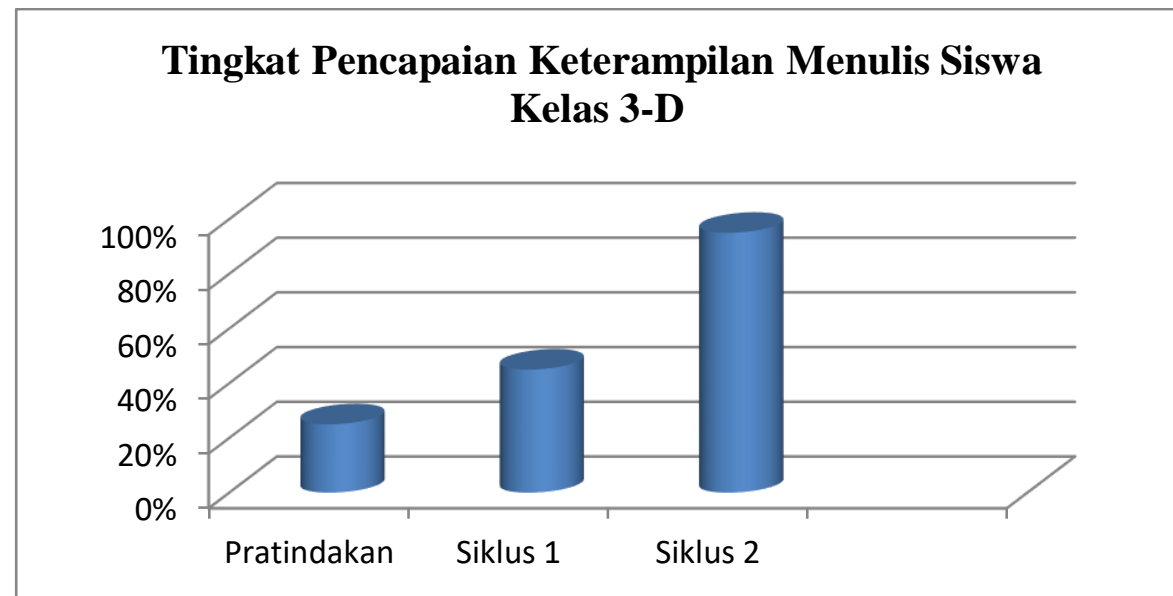

Gambar 2. Diagram Perkembangan Pencapaian Keterampilan Menulis Siswa Kelas 3-D

Pada pratindakan, diketahui bahwa guru tidak menggunakan media dalam pembelajaran. Untuk meningkatkan maka dilakukan tindakan I dengan menggunakan media pada program morning activities.

Pada tindakan I, media yang digunakan adalah diary dengan memanfaatkan program morning activities, antara lain senam AEK (Alfabet Engram Kinestetik) dan membaca lantang tanpa diulang. Agak sedikit berbeda, pada tindakan II, media yang digunakan adalah diary dengan memanfaatkan program morning activities, antara lain: AEK dan membaca lantang yang diulang. Selain itu, guru memberikan arahan dan penekanan akan pentingnya kepaduan kalimat dan penggunaan ejaan serta tanda baca. Hal tersebut semakin menguatkan siswa dalam menulis.

Dengan begitu dapat disimpulkan bahwa program morning activities yang terstruktur dan terukur dapat meningkatkan keterampilan menulis siswa kelas 3-D SDIT Insan Kamil Sidoarjo. Penggunaan media diary dalam menuliskan cerita kembali sangat berperan apalagi diperkuat dengan 
arahan dan repetisi (pengulangan) cerita yang dibacakan guru dengan lantang.

\section{KESIMPULAN}

Penelitian Tindakan Kelas (PTK) yang dilakukan untuk kelas 3-D SDIT Insan Kamil Sidoarjo berhasil dilakukan. Dengan memanfaatkan program moorning activities dengan tindakan I dan tindakan II dapat meningkatkan kemampuan menulis siswa kelas 3-D SDIT Insan Kamil Sidoarjo.

Penerapan program morning activities ini memberikan manfaat yang luar biasa bagi kelas 3-D. Program tersebut mampu membuat siswa terbiasa untuk menulis dengan kompetensi, antara lain: (1) siswa mampu memadukan antarkalimat yang satu dengan yang lain; (2) siswa mampu menuliskan cerita kembali dalam bentuk paragraf; (3) siswa mampu menuliskan cerita dengan ejaan dan tanda baca yang sesuai; (4) siswa dapat mengekspresikan dirinya dengan mengeluarkan ide, gagasan, pengalaman, dan perasaan yang dirasakan saat itu.

Hal tersebut dapat dilihat dari taraf kemampuan siswa. Mulai dari pratindakan hingga pascatindakan. Pada tahap pratindakan, prosentase kemampuan menulis siswa yang sesuai indikator hanya $30 \%$ saja.

Dari 20 subjek penelitian, 2 siswa memperoleh skor 6 (10\%), 2 siswa memperoleh skor 5 (10\%), 2 siswa lagi memperoleh skor 4 (10\%), 4 siswa memperoleh skor $3(20 \%)$, dan 10 siswa memperoleh skor 2 (50\%). Prosentase tersebut menunjukkan kualifikasi menulis siswa kelas 3-D masih rendah sehingga diperlukan tindakan.

Pada akhir tindakan I didapat hasil sebagai berikut: (1) Dari jumlah keseluruhan siswa terdapat hanya 5 siswa yang mendapat nilai $6(25 \%),(2) 4$ siswa mendapat skor 5 (20\%), (3) 6 siswa mendapat nilai 4 (30\%), dan 5 siswa mendapat nilai 3 (25\%). Dengan demikian, tindakan I masih belum bisa dikatakan berhasil sehingga memerlukan tindakan II.

Pada tindakan II didapatkan hasil yang menggembirakan. Yang awalnya hanya mencapai sekitar $45 \%$ saja dengan kategori baik, sekarang bisa mencapai 95\%. Karena masih ada 1 siswa yang belum bisa mencapai skor maksimal 6 .

Dengan hasil penelitian yang menunjukkan angka tersebut maka dapat disimpulkan bahwa tindakan yang dilakukan pada siswa kelas 3-D dapat 
meningkatkan kemampuan menulisnya. Hal tersebut nampak pada peningkatan jumlah yang siswa yang memiliki kemampuan menulis.

Perbedaan mendasar dari tindakan I dan II terletak pada cara guru dan teknik yang diberikan pada siswa. Repetisi dan penguatan terhadap siswa sangat berpengaruh pada peningkatan keterampilan menulis.

\section{DAFTAR PUSTAKA}

Amalia, Rizka. 2015. Menghidupkan Semangat Baca Anak. Duta Masyarakat, 14 Desember 2015.
Daryanto. 2011. Penelitian Tindakan Kelas dan Penelitian Tindakan Sekolah. Yogyakarta: Penerbit Gava Media.

Djago Tarigan, H.G. Tarigan. 1986. Teknik Pengajaran Keterampilan Berbahasa. Bandung: Penerbit Angkasa.

http://kbbi.kemendikbud.go.id/entri/liter asi diakses tanggal 17 Agustus 2017.

Tarigan, Henry Guntur. 1984. Membaca Sebagai Suatu Keterampilan Berbahasa. Bandung: Angkasa.

Kridalaksana, Harimurti. 1985. Tata Bahasa Deskriptif Bahasa Indonesia: Sintaksis. Jakarta: Pusat Pembinaan dan Pengembangan Bahasa. 